\begin{tabular}{|c|c|}
\hline $\begin{array}{l}\text { 2. To: (Receiving organization) } \\
\text { SST Retrieval Engineering }\end{array}$ & $\begin{array}{l}\text { 3. From: (originating Organization) } \\
\text { SST Retrieval Engineer }\end{array}$ \\
\hline $\begin{array}{l}\text { 5. Proj./Prog./Dept./Div.: } \\
W-320\end{array}$ & $\begin{array}{l}\text { 6. Design Authority/ Desion Agent/Cog. } \\
\text { Engr:- } \\
\text { J.W. Bailey }\end{array}$ \\
\hline
\end{tabular}

8. Originator Remarks:

Supporting Document Approval and Initial Release
4. Related EDT No. 620459

7. Purchese Order No.:

$N / A$

9. Equip./Component No.: N/A

10. System/Bldg./Facility: 200 E Area, Tank 241-C-106

11. Receiver Renarks: 11A. Design Basel ine Document? [X] Yes [] No
12. Major Assm. Dwg. No.: $\mathrm{H}-2-818423$

13. Permit/Permit Application Ho.: $N / A$

14. Required Response Date: N/A

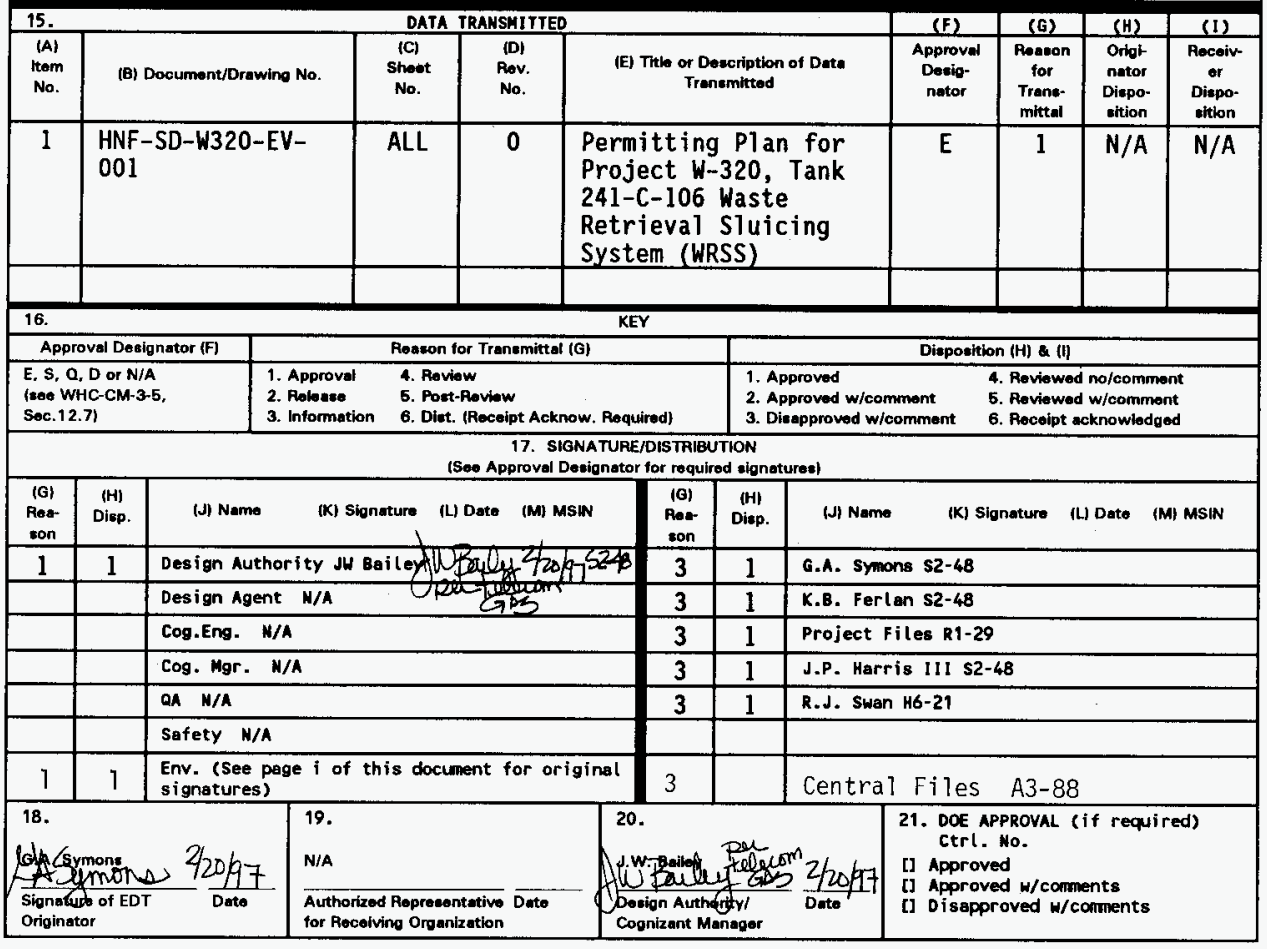

BD-7400-172-2 (05/96) GEF097 


\title{
Permitting Plan for Project W-320 Tank 241-C-106 Waste Retrieval Sluicing System (WRSS)
}

\section{G.A. Symons}

SGN Eurisys Services Corporation, Richland, WA 99352

U.S. Department of Energy Contract DE-AC06-96RL13200

\author{
EDT/ECN: 610590 - 13 UC: 510 \\ Org Code: 08E00 Charge Code: D2MP6 \\ B\&R Code: EW3130010 Total Pages: 42
}

Key Words: Tank 241-C-106, Retrieval Demonstration Tank, WRSS,

Abstract: This permitting plan has been prepared based on the Tank 241C-106 Functional Design Criteria, the Work Plan to provide permitting support for the Tank 241-C-106 Waste Retrieval.

TRADEMARK DISCLAIMER. Reference herein to any specific comercial product, process, or service by trade name, trademark, manufacturer, or otherwise, does not necessarily constitute or imply its endorsement, recommendation, or favoring by the United States Government or any agency thereof or its contractors or subcontractors.

Printed in the United States of Mmerica. To abtain copies of this document, contact: Document Control Services, P.0. Box 950, Mailstop H6-08, Richland HA 99352, Phone (509) 372-2420; Fax (509) 376-4989.
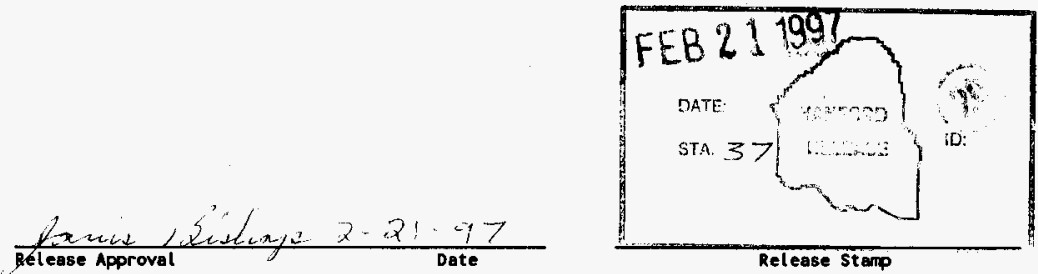
HNF

JHIC-SD-W320-EV-001 REV 0

Grs

2/20/47

PERMITTING PLAN

FOR

PROJECT W-320

TANK 241-C-106 WASTE RETRIEVAL SLUICING SYSTEM (WRSS)

\section{PERMITTING PLAN TEAM MEMBERS}

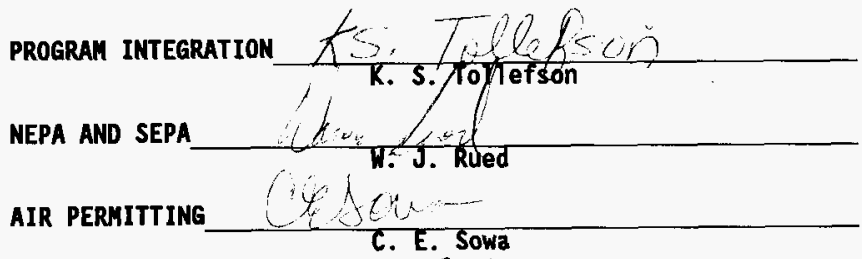
RCRA PERMITtING HM. Con. Olime

\section{PROJECT ENGINEER}

TANK WASTE PROJECTS 
HNF

WHK-SD-W320-EV-001 REV 0

GAS

2/20/97

(This page left intentionally blank.) 


\section{HNF \\ WATC-SD-W320-EV-001 REV 0
GPS/47}

\section{EXECUTIVE SUMMARY}

This document describes the permitting $\mathrm{plan}$ for Project $\mathbf{W}-320$, Tank 241-C-106 Waste Retrieval Sluicing System (WRSS).

A comprehensive review of environmental regulations have indicated that severa] environmental reviews [e.g. National Environmental Policy Act (NEPA), State Environmental Policy Act (SEPA)], permits, and approvals are required prior to construction or operation of the facility. The environmental reviews, permits and approvals, as well the regulatory authority, potentially applicable to the Tank 241-C-106 WRSS include the following:

NEPA - U.S. Department of Energy-Headquarters (DOE-HO)

- Action Description Memorandum

- Environmental Assessment

- Categorical Exclusion

- Environmental Impact Statement

SEPA - State of Washington Department of Ecology (Ecology)

- Determination of Nonsignificance

- Mitigated Determination of Nonsignificance

- Determination of Significance

- SEPA Environmental CheckTist

Air Permitting (See each Air Program)

- National Emission Standards for Hazardous Air Pollutants Permit U.S. Environmental Protection Agency (EPA)

- Prevention of Significant Deterioration - Ecology

- Radiation Protection - Air Emissions (WAC 246-247) - State of Washington Department of Health (DOH)

- New Sources of Toxic Air Pollutants - Ecology

- National Emissions Standards for Hazardous Air Pollutants (NESHAPs) Notification of Startup - EPA

Dangerous Waste Permitting (See each Program)

- Dangerous Waste Permit - Ecology

- Research, Development, and Demonstration Permit - EPA 
Miscellaneous Reviews/Permits/Approvals

- Preoperation Monitoring of Facilities, Sites and 0perations U.S. Department of Energy, Richland Field Office (RL)

- Floodplain/Wetlands Assessment - RL

- Cultural Resource Review Clearance - RL

- Excavation Permit - RL

- Endangered Species ApprovaT - RL

- Larger Onsite Sewage System Permit - DOH

This document describes the environmental reviews (e.g. NEPA, SEPA), permits and approval requirements for the project. It provides a summary of permit application data requirements, alternative strategies for permit completion and approval as well as the estimated probability of success for each alternative strategy. 


\section{HNF
SHAC-SD-W320-EV-001 REV O
S/20/97}

\section{CONTENTS}

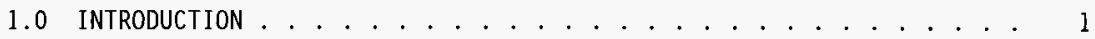

2.0 NATIONAL ENVIRONMENTAL POLICY ACT . . . . . . . . . . . . . 3

2.1 INTRODUCTION . . . . . . . . . . 3

2.2 SUMMARY OF DATA/INFORMATION REQUIREMENTS FOR THE TANK 241-C-106 WRSS . . . . . . . . . . . . . 3

2.3 DISCUSSION OF ALTERNATIVES FOR THE TANK $24 \dot{1}-\mathrm{C}-106$ WRSS $\ldots 4$

2.4 SCHEDULE PERMITTING STRATEGY . . . . . . . . . . . . 4

3.0 STATE ENVIRONMENTAL POLICY ACT . . . . . . . . . . . . . 5

3.1 INTRODUCTION ..................... 5

3.2 SUMMARY OF DATA/INFORMATION REQUIREMENTS FOR THE TANK $24 \dot{1}-\dot{C}-10 \dot{6}$ WRSS . . . . . . . . . . . . 6

3.3 DISCUSSION OF ALTERNATIVES FOR THE TANK 241-C-106 WRSS . . . 6

3.4 SCHEDULE PERMITTING STRATEGY . . . . . . . . . . . . . 6

4.0 RESOURCE CONSERVATION AND RECOVERY ACT . . . . . . . . . . 7

4.1 INTRODUCTION ...................... . . . 7

4.2 SUMMARY OF DATA/INFORMATION REQUIREMENTS FOR THE TANK 241-C-106 WRSS . . . . . . . . . . . . . . . . . 9

4.3 DISCUSSION OF ALTERNATIVES FOR THE TANK 241-C-106 WRSS .... 9

4.4 SCHEDULE PERMITTING STRATEGY . . . . . . . . . . . . 10

5.0 THE CLEAN AIR ACT . . . . . . . . . . . . . . . 11

5.1 INTRODUCTION . . . . . . . . . . . . . . . . . . 11

5.2 SUMMARY OF DATA/INFORMATION REQUIREMENTS FOR NESHAP AND

WAC 246-247 PERMIT APPLICATIONS AND NOTICE OF CONSTRUCTION . . 13

5.3 DISCUSSION OF ALTERNATIVES FOR THE TANK $241-C-106$ WRSS $\ldots \ldots 13$

5.4 SCHEDULE PERMITTING STRATEGY . . . . . . . . . . . . . 13

6.0 MISCELLANEOUS ASSESSMENTS, PERMITS, AND APPROVALS . . . . . . . 15

6.1 CULTURAL RESOURCE REVIEW . . . . . . . . . . . . . 15

6.2 EXCAVATION PERMIT . . . . . . . . . . . . . . . . . . . . . 15

6.3 ENDANGERED SPECIES ACT COMPLIANCE . . . . . . . . 15

6.4 PREOPERATION MONITORING OF FACILITIES, SITES, AND OPERATIONS . 15

6.5 LARGER ONSITE SEWAGE SYSTEM PERMIT . . . . . . . . 15

GLOSSARY . . . . . . . . . . . . . . . . . 17

FIGURE - PROJECT W-320 PERMITTING SCHEDULE $\ldots \ldots$

FIGURE - PROJECT W-320 PERMITTING SCHEDULE . . . ........ 21

FIGURE - PROJECT W-320 PERMITTING SCHEDULE ........... 23

FIGURE - PROJECT W-320 PERMITTING SCHEDULE . . . . . . . . . . 25

APPENDIX . . . . . . . . . . . . . . . . . . . 27 


\section{HW \\ WHCC-SD-W320-EV-001 REV 0 \\ 2/20/97}

(This page left intentionally blank.) 


\section{HNF \\ WHT-SD-W320-EV-001 REV 0 \\ 2/20/97 \\ PERMITTING PLAN \\ FOR \\ PROJECT W-320 \\ TANK 241-C-106 WASTE RETRIEVAL SLUICING SYSTEM (WRSS)}

\subsection{INTRODUCTION}

This document describes permitting requirements for design, construction and demonstration of waste retrieval technology from single-shell tanks. Milestone M-07-00, established in the Hanford Federal Facility Agreement and Consent Order, otherwise known as the Tri-Party Agreement, requires waste retrieval from Hanford Site Single-Shell Tanks (SSTs) as the initial phase of SST closure. Tank 241-C-106 has been identified as the M-07-00 retrieval demonstration tank. For purposes of this document, decontamination is defined as a reduction in radioactive contamination to minimize occupational exposure.

In support of waste retrieval, it is necessary to remove existing equipment and install new equipment in Tanks 241-C-106 and 241-AY-102. The levels of contamination in the pits and on the equipment are extremely high resulting in unacceptable personnel exposure rates. Therefore, it is mandatory to reduce the radiation exposure, as much as possible, to allow for personne1 access to remove and install equipment. Carbon dioxide (CO2) decontamination and/or a standard water/stream jetting system will be utilized for both decontamination of the C-106 pump, heel and sluice pits, and for decontamination of the pumps as they are extracted from the tanks into the receivers. The pumps will then be inserted into a container for transportation to interim storage.

Project $W-320$ is intended for mobilization and removal of the heatgenerating sludge in Tank 241-C-106 to resolve the high-heat safety issue. Tank-to-tank sluicing, an existing technology, will provide the earliest possible closure of this safety issue. Removal of the heat-generating sludge will allow cooling water additions to cease. The cessation of cooling water additions will allow operations to place Tank 241-C-106 in a safe, interim stabilized state. Additional retrieval operations can proceed using alternate technology, as required, to achieve $95 \%$ waste retrieval according to the terms of the Tri-Party Agreement Milestone M-07-00. Waste from Tank 241-C-106 has been identified as an early feed to the Hanford Waste Vitrification Plant (HWVP) because the material requires only simple sludge washing pretreatment prior to vitrification. This retrieval action is required to maintain HWVP operations continuity following initial Double-She11 Tank (DST) waste from neutralized current acid waste from Tanks 241-AZ-101 and 241-AZ-102.

The Tank 24l-C-106 WRSS will be designed to remove the radioactive and chemical sludge from Tank 241-C-106, and transport that material to the 241-AY-102 DST via a new, temporary, above grade, shielded, encased transfer 1ine. The system will include hardware specific to retrieval of waste tank contents, all supporting structures, facilities

(including control room, lunchroom, and sanitary facilities), waste tank modifications, receiver tank system modifications necessary to retrieve Tank 241-C-106, the transfer line to and from the DST system, and al1 


\section{GPS HWHF}

associated support equipment. A11 Tank 241-C-106 process components and supporting equipment sha11 have a design life of two years including twelve months for retrieval operations.

This permitting plan has been prepared based on the Tank 24l-C-106 Functional Design Criteria, the Work Plan to provide permitting support for Tank 241-C-106 Waste Retrieval, and the added scope of the $\mathrm{CO}_{2}$ decontamination demonstration. 


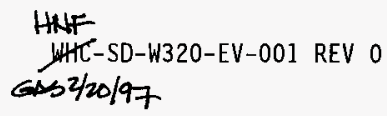

\subsection{NATIONAL ENVIRONMENTAL POLICY ACT}

The NEPA 42 U.S.C. 4321 et seq, was enacted to ensure that environmental matters are considered prior to initiation of federal actions which may affect the quality of the human environment. The DOE regulations ( 10 Code of Federal Regulations [CFR] 1021) promulgated under NEPA were developed to assess the environmental impacts associated with specific DOE proposals or actions.

\subsection{INTRODUCTION}

If a proposed action appears to be covered under an existing approved environmental impact statement (EIS) or environmental assessment (EA), the relevant Record of Decision or Finding of No Significant Impact (FONSI) should be examined to ensure the proposed action is adequately bounded by existing documentation.

In the event that $\mathrm{RL}$ determines that a proposed action is not covered by existing environmental documentation, an evaluation would be required to determine whether the proposed action falls within one of the categorical exclusions $(C X)$. If the proposed action is covered by a $C X$, then an information bulletin (IB) is prepared that summarizes the proposed action and its background. In addition, an explanation of how the action meets the minimum requirements of a $C X$ is needed.

If the proposed action is not covered by a $C X$, then an action description memorandum (ADM) is developed. The ADM provides a brief but concise description of the proposed action, the potentially affected environment, and possible environmental impacts. Al1 ADMs are sent to RL, and may be subsequently transmitted to DOE-HQ to determine if the proposed action warrants an EA or an EIS.

The EA is developed to discuss the environmental consequences of the proposed action and the alternatives to that action, including: the consequences of accidents and routine operations, and the cumulative and long term impacts. A discussion of the relationship of the proposed action to federal, state, and local land use plans, policies, and regulations is also discussed in the EA. EAs are submitted to RL for review and are then transmitted to DOE-HQ for final determination made by the Assistant Secretary for Environment, Safety and Health. This determination will result in a decision that the proposed action is a major action significantly affecting the environment, requiring an EIS, or issuance of a FONSI.

\subsection{SUMMARY OF DATA/INFORMATION REQUIREMENTS FOR THE TANK 241-C-106 WRSS}

See Appendix, Section 1.0 for a summary of the minimum data/information needs required for development of the NEPA documentation for the Tank 24l-C-106 WRSS. 


\subsection{DISCUSSION OF ALTERNATIVES FOR THE TANK 241-C-106 WRSS}

Various NEPA compliance alternatives may be available in an effort to support the Tank 241-C-106 WRSS. The probability of success (high, medium, low) will follow each 1isted alternative. See Figure for the $W-320$ permitting schedule.

1. To determine the most appropriate type of NEPA coverage, an ADM can be prepared. This would likely result in a determination that an EA is required. The desired outcome of the EA would be a FONSI, after which the project could proceed. The scope of work covered included under the $\mathrm{CO}_{2}$ blasting will be covered by the routine maintenance $\mathrm{CX}$. (High)

2. Same as alternative one but the outcome of the $E A$ is a requirement to prepare an EIS. (Low)

3. Alternative three is the possibility of NEPA coverage of the Tank 241-C-106 WRSS under the Hanford Defense Waste EIS. This alternative has been explored and guidance was provided from DOE-HQ to prepare an ADM/EA. (Low)

\subsection{SCHEDULE PERMITTING STRATEGY}

For design, construction, and demonstration of the Tank 241-C-106 WRSS, an ADM/EA will be prepared. The assumed outcome of this ADM/EA is a FONSI. 


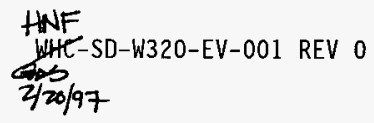

\subsection{STATE ENVIRONMENTAL POLICY ACT}

The SEPA, Chapter 43.21C Revised Code of Washington legislation which requires evaluation of environmental impacts associated with a project or an agency action prior to approval. The SEPA Rules, Chapter 197-11 Washington Administrative Code (WAC), are the implementing regulations.

\subsection{INTRODUCTION}

One agency is identified as lead agency for each project. The lead agency is responsible for assuring that SEPA compliance is completed prior to approving the proposed project. SEPA compliance is required for any project or proposal which meets the definitions of "action" in the SEPA Rules. See WAC 197-11-704. This includes projects which require a permit (e.g., Hazardous Waste Permit, Building Permit) or other approval from a governmental agency prior to operation. At the Hanford Site, Ecology is the lead agency for projects ("Actions") involving. permitting of hazardous waste treatment, storage, or disposal facilities.

The SEPA compliance for a given project is completed prior to the lead agency making a decision to approve the project. At the Hanford Site, a SEPA environmental checklist is prepared prior to submittal of the first permit application to Ecology. The SEPA environmental checklist must accompany the permit application. The permit/approval may be conditioned or denied based on information in the SEPA environmental check1ist. SEPA compliance is required, in addition to the normal permits or approvals, for a project.

When SEPA compliance is required for a project, the responsible official of the lead agency must make a threshold determination by deciding if a project is likely to have probable significant adverse impacts on the environment. If a project may have significant adverse impacts, a Determination of Significance (DS) will be issued and a State Environmental Impact Statement (SEIS) may be required. If the project will not have significant adverse impacts, or if the impacts can be mitigated, a determination of nonsignificance (DNS) or mitigated DNS will be issued. The threshold determination is normally based on the environmental check 1 ist completed for the project and any information which the lead agency has on file.

The SEPA allows the lead agency to adopt a NEPA EA or EIS in 1ieu of doing additional review under SEPA (WAC 197-11-610). See Figure Project $W-320$ Permitting Schedule, pages 19-27 for the Project $W-320$ permitting schedule. 


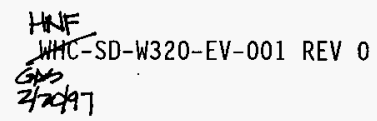

\subsection{SUMMARY OF DATA/INFORMATION REQUIREMENTS FOR THE TANK 241-C-106 WRSS}

See Appendix, Section 2.0 for a summary of the minimum data/information needs required for development of the SEPA documentation for the Tank 241-C-106 WRSS.

\subsection{DISCUSSION OF ALTERNATIVES FOR THE TANK 241-C-106 WRSS}

Various SEPA avenues may be evaluated in an effort to support the Tank 241-C-106 WRSS. The alternatives open for consideration are discussed below. The probability of success (high, medium, low) will follow each listed alternative.

1. A DNS from the State for the Tank 241-C-106 WRSS. (High)

2. DS by the State. Subsequent Adoption of NEPA documentation by the State for the Tank 241-C-106 WRSS. (Medium)

3. A mitigated DNS from the State. (Low)

4. DS from the State and requirement to prepare separate State EIS. (Low)

\subsection{SCHEDULE PERMITTING STRATEGY}

A SEPA environmental checklist must be prepared for the Tank 241-C-106 WRSS. This checklist should accompany the Notice of Intent (NOI) which is the first step in the Resource Conservation and Recovery Act (RCRA) Permitting process. The state may issue a DNS for the Tank 241-C-106 WRSS and adopt the NEPA documentation. 


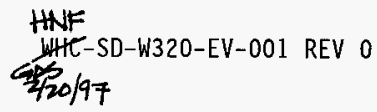

\subsection{RESOURCE CONSERVATION AND RECOVERY ACT}

The RCRA, 42 U.S.C. 6901 et seq. was enacted as a comprehensive national program to mandate that hazardous waste will be treated, stored and disposed of so as to minimize the present and future threat to human health and the environment. In the State of Washington, the Dangerous Waste Regulations, WAC 173-303, are the implementing regulations.

\subsection{INTRODUCTION}

The Dangerous Waste Regulations apply to all facilities within Washington State that treat, store and/or dispose (TSD) of dangerous waste. These regulations are equivalent to, or more stringent than, the federal hazardous waste regulations. Under the dangerous waste program all TSD facilities must obtain a permit. Facilities which were in existence on November 19, 1980, were granted an Interim Status permit with the submittal of a Part A permit application identifying their intent to TSD of dangerous waste. Interim Status ends after final administrative disposition of a Part B permit application is completed and either a Final Status permit is denied or granted. All new construction requires that a Final Status permit be granted before initiating construction, defined by Ecology as ground breaking.

Expansion of an existing Interim Status facility, comprising of less than $50 \%$ of the existing capital investment, can proceed under Interim Status. Expansion to an existing Interim Status facility, comprising of $50 \%$ or more of the existing capital investment, requires a Final Status permit before initiating construction. Once a facility has been granted a Final Status permit, expansion or modification to that facility requires a modification to the Final Status permit in accordance with WAC 173-303-830. Pilot Plants used to provide research or demonstrate treatment technologies could require a Research, Development, and Demonstration (RD\&D) permit in accordance with 40 CFR 270. The RD\&D permit is administered by EPA and must be obtained before initiating construction.

An application for a dangerous waste management permit consists of three collective submittals. Each submittal consists of various levels of detailed information concerning the facility. The three submittals are the NOI, the Part A permit application (Part A), and the Part B permit application (Part B). See Figure - Project W-320 Permitting Schedule, pages 19-27 for the Project $W-320$ permitting schedule.

\section{Notice of Intent}

The NOI identifies an applicant's intent to construct and operate a TSD facility in accordance with WAC 173-303-281. In addition, an NOI can identify the expansion of an existing TSD facility. The NOI contains preliminary information concerning the proposed facility and/or expansion. The NOI requires a general process description, operating capacities, waste type, development and submittal of a SEPA CheckTist, a topographic map, and a statement of environmental conditions. 


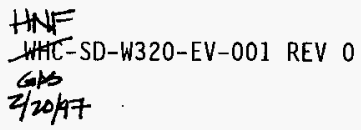

In accordance with WAC 173-303-281, the NOI must be submitted to the Ecology and the public reading rooms, and a public notification published in a local daily newspaper, at least 150 days prior to submittal of the Part A permit application. The NOI process normally requires approximately 11 months to complete, which at the completion of the Public Review period, the Part $A$ permit application is submitted.

\section{Part A}

The Part A consists of completing the Dangerous Waste Part A permit application, Forms 1 and 3 . The Part A can be submitted no earlier than 150 days after the NOI is published. The Part A can be submitted concurrently with the Part B; however, in most instances the Part $A$ is filed in advance of the Part B. The Part A preparation process (following the submittal of the NOI) requires approximately 5 months to complete, including the WHC/RL review and certification requirements.

\section{Part B}

The Part B consists of detailed design, technical, operational, maintenance, engineering, training, closure, and other relevant information concerning the waste management facility, in accordance with the Part $B$ checklist provided by Ecology. The information is presented in a narrative format, often utilizing extensive figures, tables, and design media.

The Part B is evaluated by the agencies for completeness and technical adequacy. The latter includes plausibility, general detail of plans and procedures, and protection of the environment. For any item deemed incomplete or technically inadequate, Ecology issues a Notice of Deficiency (NOD) to the applicant. The applicant responds to the NOD and if accepted by Ecology, modifications are made to the Part B as necessary. The "NOD/response/Part B revision" iterative phase takes a minimum of 360 days and often longer depending on the agency's manpower resources, acceptance of the application concept, or if regulatory requirements change in the interim.

When satisfied with the Part B, Ecology prepares a draft permit. The draft permit enforces permit provisions and may reference sections of the final Part B permit application. This draft permit is published for public and interagency review. Upon completion of the public review period, significant public comments are factored into the final status permit issued by Ecology. For the Hanford Site, one Dangerous Waste Permit will be issued for the Hanford Facility. Upon completion of the unit specific Part B permit application process, each unit will be appended to the Hanford Facility Dangerous Waste Permit. Once appended, construction of new management facilities may commence. Generally, preparation of a Part B application requires approximately 14 months, through the first certification cycle, and the total duration may last approximately 6 years. 


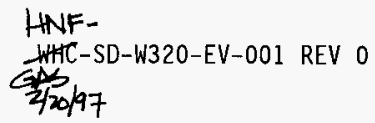

In some cases, Ecology and EPA have granted interim status expansion, which removes the constraint of issuance of the permit from the start of construction. This requires negotiation with the agencies, and is not always approved. If Ecology and EPA grant interim status expansion under the DST/SST Part $B$, construction could proceed once the revised Part $A$ was submitted and interim status granted by the agencies.

\subsection{SUMMARY OF DATA/INFORMATION REQUIREMENTS FOR THE TANK 241-C-106 WRSS}

See Appendix, Section 3.0 for a summary of the minimum data/information needs required for development of RCRA permit applications.

\subsection{DISCUSSION OF ALTERNATIVES FOR THE TANK 241-C-106 WRSS}

Various avenues may be evaluated in an effort to support the Tank 241-C-106 WRSS. The alternatives open for consideration are discussed below. The probability of success (high, medium, low) will follow each listed alternative.

1. Submittal of a NOI and modification of the Part A permit application for the SST System. A revision to the DST Part B permit application will also be required. (Medium)

The assumptions include the following:

(a) Waste types identified in the Waste Compatibility Evaluation are different from those already described in the SST Part A, but are the same for the DST.

(b) Process activities include treatment technologies not already identified in the SST Part A.

(c) Regulators do not allow additional treatment under closure and require a NOI. (Some treatment can be performed in the "name" of closure without a NOI. They just have to modify the Part A permit application.)

(d) The design does not increase the equipment capacities or volumes for the DST System.

2. Prepare and submit a NOI and modify the Part A permit application for the SST System. Prepare and submit a NOI, and modify the Part A and B permit applications for the DST System. (Medium)

The assumptions include the following:

(a) Same as assumption (a) above. 


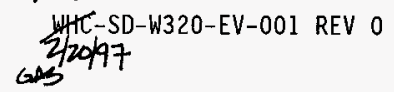

(b) Same as assumption (b) above except it also includes the DST system.

(c) Same as assumption (c) above.

(d) The design increases the equipment capacities or volumes for the DST System.

3. No NOI/Part A revision is required for the SST and DST A Systems. The DST Part $B$ will require revision. The revision to the DST Part $B$ will include a description of the ancillary equipment and the source of the waste. (High)

The assumptions include:

(a) Waste codes are the same as those identified in the SST Part A.

(b) Process activities do not include treatment technologies that are different than those identified in the SST or DST Part A.

(c) The design does not increase equipment capacity or volumes for the SST System or the DST System.

\subsection{SCHEDULE PERMITTING STRATEGY}

The existing Part A permit application will require modification for the SST and/or DST Systems. The treatment description included in the SST Part A will be revised to allow for the retrieval of the solids, interstitial liquids, and cooling liquid waste. Modification of the DST Part B permit application will also be required to identify the SST waste as an influent source. The assumed outcome is approval to expand under interim status.

A recommendation has been made by the WHC RCRA Compliance Support Function to modify Waste Tanks DST system, and SST system, Part A Permit Applications to include long length equipment treatment activities when equipment is pulled from the tank and/or the rinsate is allowed to go back into the tank. Water washing activities should be covered along with potential physical and chemical extraction technologies that could be used. A final decision has not been made to act on these recommendations. Because these modifications affect all tank farm activities, the revisions to the permit applications will be completed as a separate effort from Project $W-320$. 


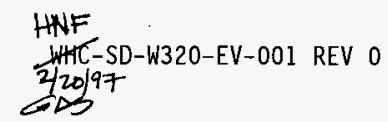

\subsection{THE CLEAN AIR ACT}

The Federal Clean Air Act (CAA), 42 U.S.C. 7401 et seq. was enacted in 1970, amended in 1977, and overhauled and expanded in 1990.

\subsection{INTRODUCTION}

The installation and demonstration of the Tank 241-C-106 WRSS will require several permits and approvals prior to construction, treatment and disposal of the influent waste stream. These permits and approvals will be issued by several regulatory agencies, including the EPA, ECology, DOH, and the Benton, Franklin, Walla Walla Counties Air Pollution Control Authority (APCA). See Figure - Project W-320 Permitting Schedule, pages 19-27 for the Project $W-320$ permitting schedule.

Permitting and emission standards administered by these agencies are contained in the following regulations:

- NESHAPS [40 Code of Federal Regulations (CFR) 61 Subpart H]

- Prevention of Significant Deterioration (PSD) standards (40 CFR 52.21) and (WAC 173-400)

- Ambient Air Quality Standards for Radionuclides (WAC 173-480)

- Radiation Protection - Air Emissions (WAC 246-247)

- Controls for New Sources of Toxic Air Pollutants (TAPs) (WAC 173-460).

\section{Radioactive Emissions}

Radioactive air emissions are currently regulated by both the EPA, pursuant to $40 \mathrm{CFR} 61$ Subpart $H$, and the DOH, pursuant to WAC 246-247. Both regulations require preconstruction approval from the respective agencies. Additionally, the $\mathrm{DOH}$ requires extensive information on the technologies chosen to control radioactive air emissions, including an assessment of all known control technologies. This assessment, referred to as a Best Available Radionuclide Control Technology (BARCT) assessment, is normally prepared by consulting firms and evaluates the universe of available control technologies. For Tank 241-C-106 WRSS, the project must install the "Best" technology, as determined by the BARCT assessment. The EPA also requires the sampling and monitoring system to meet specific criteria. This criteria, including requirements on the placement and number of sample probes, is applicable if the estimated dose equivalent from the facility to the maximally exposed offsite individual is greater than 0.1 mrem per year and when, hypothetically, no emissions control equipment is in place but operations are otherwise routine. 
HNF

WAC 246-247 requires varying degrees of information dependent on the quantity of emissions. It is expected that the will require the highest level of information for the WAC 246-247 application, and will require preconstruction approval under the NESHAPS regulations.

Prior to starting the BARCT assessment, extensive information on the processes and expected emissions from those processes must be developed. This information is required to perform an adequate BARCT assessment. Information not normally available until definitive design (particularly concerning sampling equipment and expected emissions) is crucial to the preparation of the permit applications.

\section{Nonradioactive Emissions}

Nonradioactive air emissions of concern are expected to fall into one of two categories: criteria pollutants and toxic air pollutants.

Criteria pollutants are those pollutants subject to the PSD program, enforced in Washington by Ecology. Ecology has incorporated by reference most of the Federal PSD requirements. The Tank 241-C-106 WRSS is not expected to have emissions exceeding the trigger levels for criteria pollutants.

TAPs are a separate class of emissions, regulated pursuant to WAC 173-460 by Ecology. Over 500 carcinogenic and toxic pollutants are included in this regulation. Because emissions will occur during demonstration of the Tank 241-C-106 WRSS, WAC 173-460 is applicable, and there is no de minimis level below which preconstruction approval is not required. While WAC 246-247 requires installation of BARCT, the TAPs regulations require the installation of Best Available Control Technology for Toxics (T-BACT). Additionally, if emissions of pollutants (after controls) exceed the small quantity emission (SQE) rates included in the regulations, modeling must be performed to demonstrate that the offsite concentration of each pollutant of concern does not exceed the Acceptable Source Impact Levels. Some pollutants do not have SQE rates, and modeling is required for any level of emission.

If any Criteria pollutant approaches its trigger level, the information required by the PSD process would be included in a single application to Ecology. Ecology refers to these air permit applications as Notice of Constructions (NOCs). 
HNE

WHC-SD-W320-EV-00I REV 0

2/20/97

\subsection{SUMMARY OF DATA/INFORMATION REQUIREMENTS FOR NESHAP AND WAC 246-247 PERMIT APPLICATIONS AND NOTICE OF CONSTRUCTION}

See Appendix, Section $\mathbf{4 . 0}$ for a summary of the minimum data/information needs required for development of each of the air permit applications.

\subsection{DISCUSSION OF ALTERNATIVES FOR THE TANK 241-C-106 WRSS}

Various avenues may be evaluated in an effort to support the air permitting for the demonstration of the Tank 241-C-106 WRSS. Demonstration the Tank 241-C-106 WRSS may require submittal of all of the 1 isted applications. The length of the permitting process is dependant on the quantity of emissions and facility inventory. The alternatives open for consideration are discussed below. The probability of success (high, medium, low) will follow each listed alternative. The permitting process can be shortened by providing the necessary information as soon as it is available. See Figure for the Project $W-320$ permitting schedule.

1. Obtain WAC $246-247,40$ CFR 61 Subpart H (NESHAPs), and WAC 173-460 (TAPs) approvals when all information, necessary to complete the applications, is available. (High)

2. Obtain WAC 246-247, 40 CFR 61 Subpart H (NESHAPs), and WAC 173-460 (TAPs) approvals in a phased approach. The first phase would include obtaining approval for all construction activities not directly associated with the ventilation system. The second phase would obtain approval for construction activities associated with the exhauster and ventilation system. (Medium)

\subsection{SCHEDULE PERMITTING STRATEGY}

Due to schedule considerations, the phased approach is the recommended strategy. It is assumed that an application for approval to construct will be submitted for WAC 246-247, 40 CFR 61 Subpart $H$ (NESHAPs), and WAC 173-460 (TAPS). It is assumed that the demonstration will not have emissions exceeding significance levels for any criteria pollutants under the PSD program. Installation of BARCT will be required by WAC 246-247 and T-BACT wil1 be required by the TAPs program. 


\section{HWF \\ WHTC-SD-W320-EV-001 REV 0 ars \\ $2 / 20 / 97$}

(This page left intentionally blank.) 


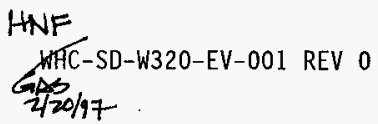

\subsection{MISCELlaNeOUS ASSESSMENTS, PERMITS, AND APPROVALS}

In addition to the major regulatory programs discussed in this permitting plan, several miscellaneous assessments, permits, and approvals need to be addressed.

\subsection{CULTURAL RESOURCE REVIEW}

A Cultural Resource Review shall be performed prior to initiating the any potential surface disturbing activities onsite (36 CFR 800 ). The regulatory agency is RL. The Cultural Resource Review shall be submitted with the EA to $\mathrm{RL}$.

\subsection{EXCAVATION PERMIT}

An excavation permit is required prior to initiating any potential surface disturbing activities onsite (36 CFR 800 ). The regulatory agency is RL. This permit will be prepared prior to construction of the tank farm interfaces.

\subsection{ENDANGERED SPECIES ACT COMPLIANCE}

A site assessment should be made to determine whether any $\mathrm{planned}$ activities have the potential to disturb any habitat used by wildlife prior to construction or habitat modification (50 CFR 402.6). The regulatory agency is the Fish and Wildlife Service. For onsite construction, a biological survey is performed by WHC. The survey report must accompany the EA when submitted to RL.

\subsection{PREOPERATION MONITORING OF FACILITIES, SITES, AND OPERATIONS}

An environmental study must be conducted prior to start up of a new site, facility, or process which has the potential for significant adverse environmental impact (DOE Order 5400.1). The regulatory agency is RL. This monitoring shall be started at least one year prior to installation of the Tank 241-C-106 WRSS.

\subsection{LARGER ONSITE SEMAGE SYSTEM PERMIT}

\section{Septic system approvals/permits (<14,500 gpd design capacity) - WAC 246-272}

Plans and specification for construction of a new sanitary sewer system or modification of an existing system shall be submitted and approved by the DOH prior to construction. Once the installation is complete, a Professional Engineer registered in the State of Washington, must certify that the installation has been installed in accordance with Plans and Specifications approved by the DOH. In addition, an Operation and Maintenance Manual must be submitted to the DOH. 


\section{HNF \\ WHTC-SD-W320-EV-001 REV 0 \\ $420 \mathrm{kT}$ \\ GAS}

(This page left intentionally blank.) 


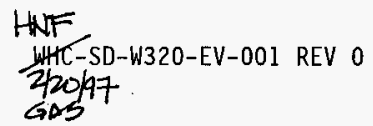

\section{GLOSSARY}

\section{ABBREVIATIONS, ACRONYMS AND INITIALISMS}

$\begin{array}{ll}\text { ADM } & \text { Action Description Memorandum } \\ \text { APCA } & \text { Benton, Franklin, Walla Walla Counties Air Pollution Control } \\ & \text { Authority } \\ \text { BARCT } & \text { Best Available Radionuclide Control Technology } \\ \text { CAA } & \text { Clean Air Act } \\ \text { CDR } & \text { Conceptual Design Report } \\ \text { CFR } & \text { Code of Federal Regulations } \\ \text { CX } & \text { Categorical Exclusion } \\ \text { DOE-HQ } & \text { U.S. Department of Energy-Headquarters } \\ \text { DOH } & \text { State of Washington Department of Health } \\ \text { DS } & \text { Determination of Significance } \\ \text { DNS } & \text { Determination of Nonsignificance } \\ \text { DST } & \text { Double-Shell Tanks } \\ \text { EA } & \text { Environmental Assessment } \\ \text { ECO1ogy } & \text { State of Washington Department of Ecology } \\ \text { EIS } & \text { Environmental Impact Statement } \\ \text { EPA } & \text { U.S. Environmental Protection Agency } \\ \text { FONSI } & \text { Finding of No Significant Impact } \\ \text { IB } & \text { Information Bulletin } \\ \text { IPM } & \text { Initial Pretreatment Module } \\ \text { NAAQS } & \text { National Ambient Air Quality Standards } \\ \text { NESHAPS } & \text { National Emissions Standards for Hazardous Air Pollutants } \\ \text { NEPA } & \text { National Environmental Policy Act } \\ \text { NOC } & \text { Notice of Construction } \\ \text { NOD } & \text { Notice of Deficiency } \\ \text { NOI } & \text { Notice of Intent - one for RCRA and one for NEPA } \\ \text { PNL } & \text { Pacific Northwest Laboratories } \\ \text { PSD } & \text { Prevention of Significant Deterioration } \\ \text { PSE } & \text { Preliminary Safety Evaluation } \\ \text { RCRA } & \text { Resource Conservation and Recovery Act } \\ \text { RD\&D } & \text { Research, Development, and Demonstration } \\ \text { RL } & \text { Department of Energy, Richland Field Office } \\ \text { SEPA } & \text { State Environmental Policy Act } \\ \text { SEIS } & \text { State Environmental Impact Statement } \\ \text { SQE } & \text { Small Quantity Exemption } \\ \text { TAPS } & \text { Toxic Air Pollutants } \\ \text { T-BACT } & \text { Best Available Control Technology for Toxics } \\ \text { TSD } & \text { Treatment, Storage, and Disposal } \\ \text { VOCs } & \text { Volatile Organic Compounds } \\ \text { WAC } & \text { Washington Administrative Code } \\ \text { WRSS } & \text { Waste Retrieval Sluicing System } \\ \end{array}$




\section{HNF \\ WHC-SD-W320-EV-001 REV 0 \\ $2 / 20197$}

(This page left intentionally blank.) 
CHEF
CW/20197 $W H+C-S D-W 320-E V-001$ REV 0

FIGURE - PROJECT W-320 PERMITTING SCHEDULE

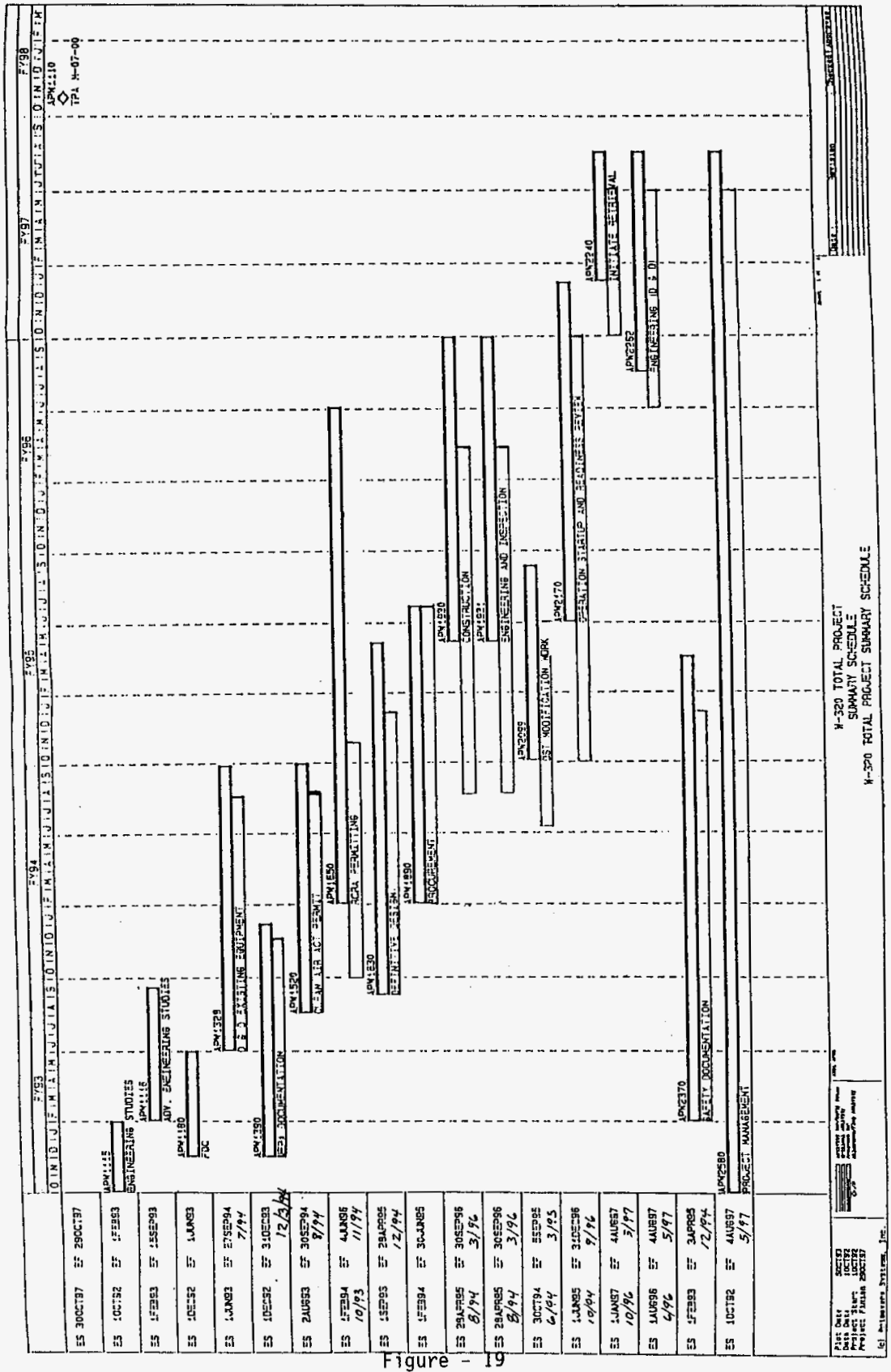




\section{HWF \\ WHC-SD-W320-EV-001 REV 0 \\ S20197}

(This page left intentionally blank.)

Figure - 20 
GNG 20197 HWE-SD-W320-EV-001 REV 0

FIGURE - PROJECT W-320 PERMITTING SCHEDULE

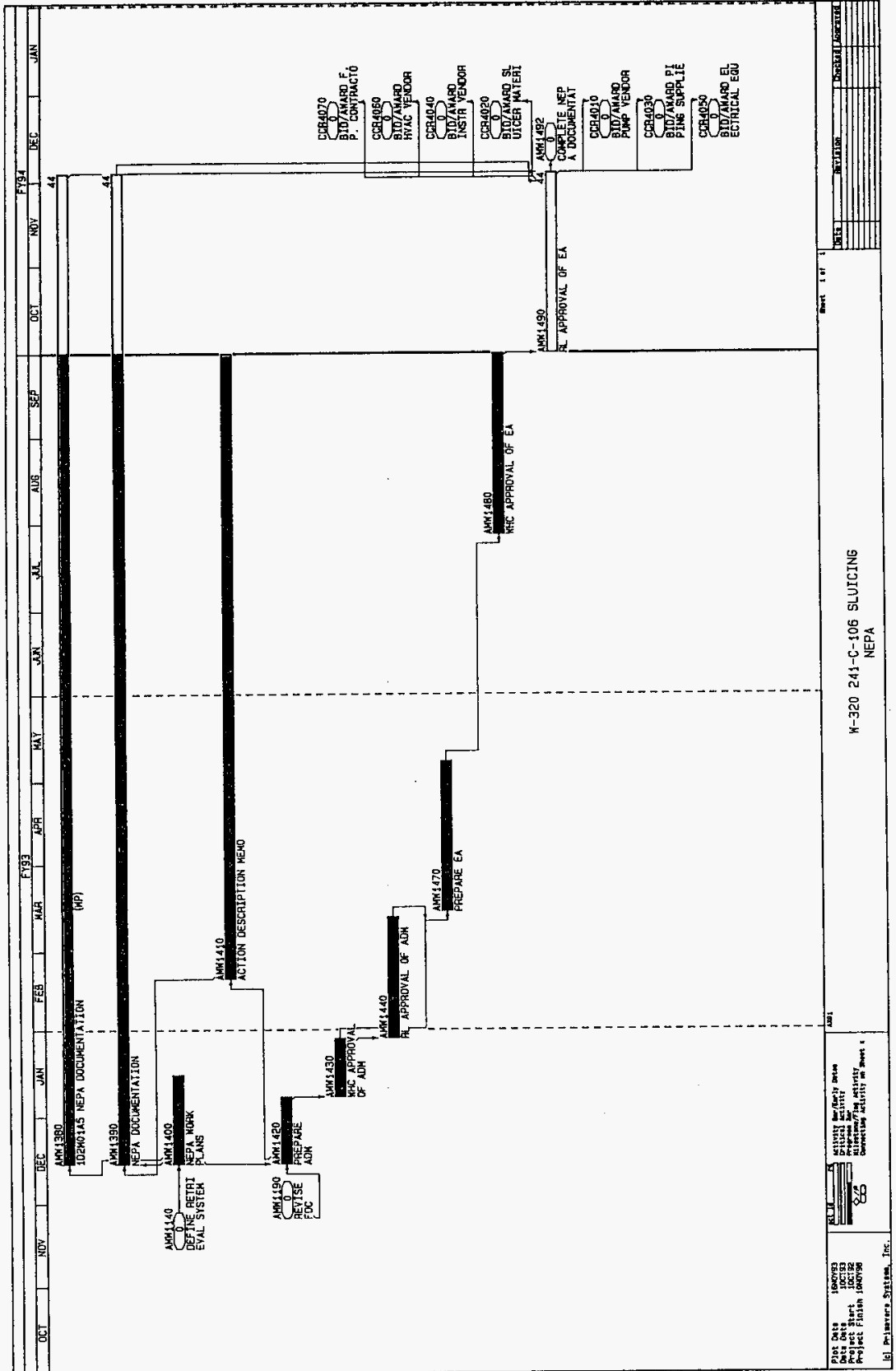




\section{$H N F$ \\ WH ClC-SD-W320-EV-001 REV 0 \\ 2holat}

(This page left intentionally blank.) 
$\varepsilon 2-\operatorname{sun} 6 !\rfloor$

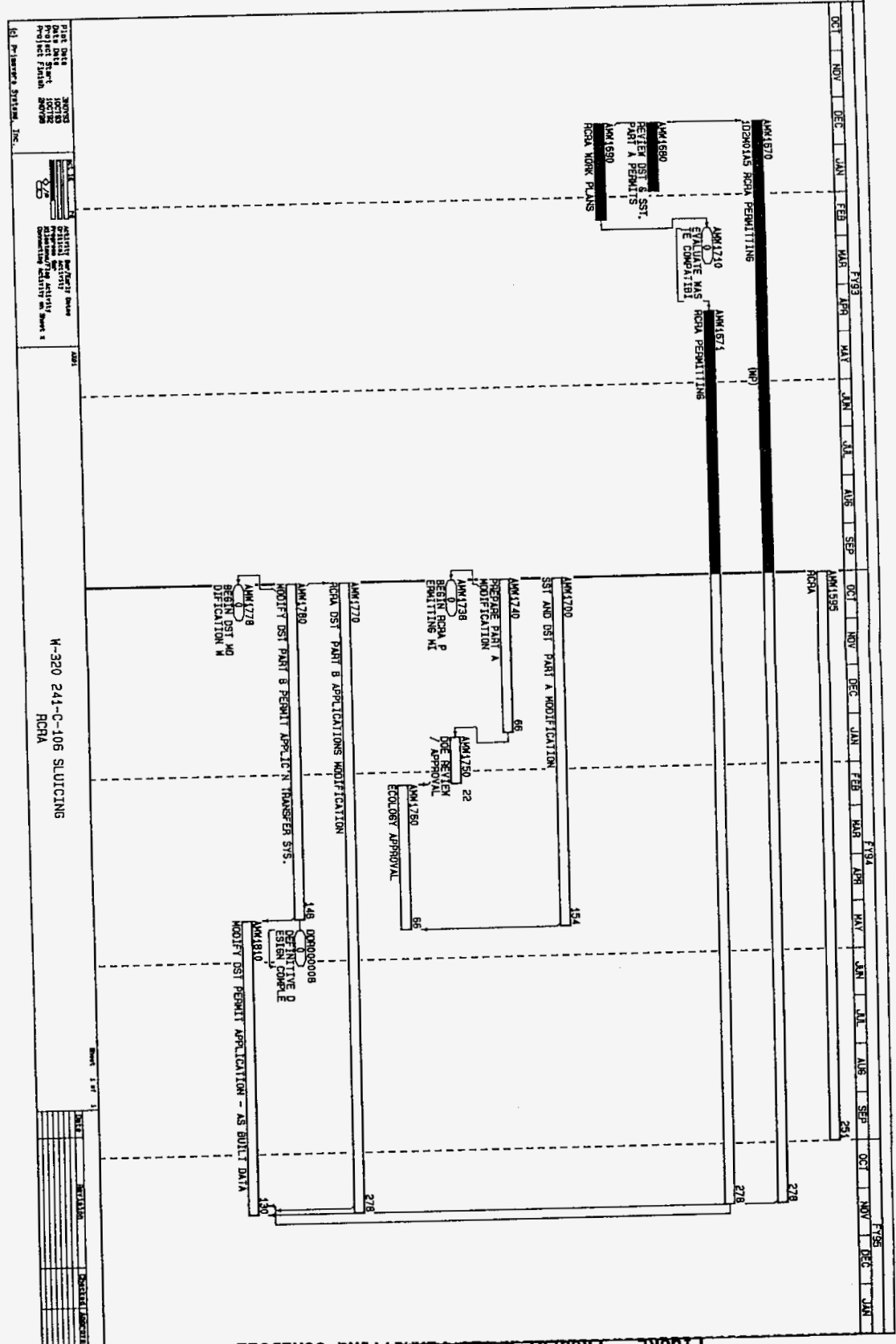




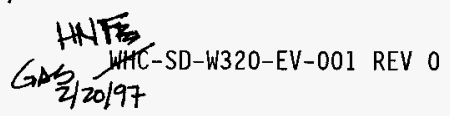

(This page left intentionally blank.) 


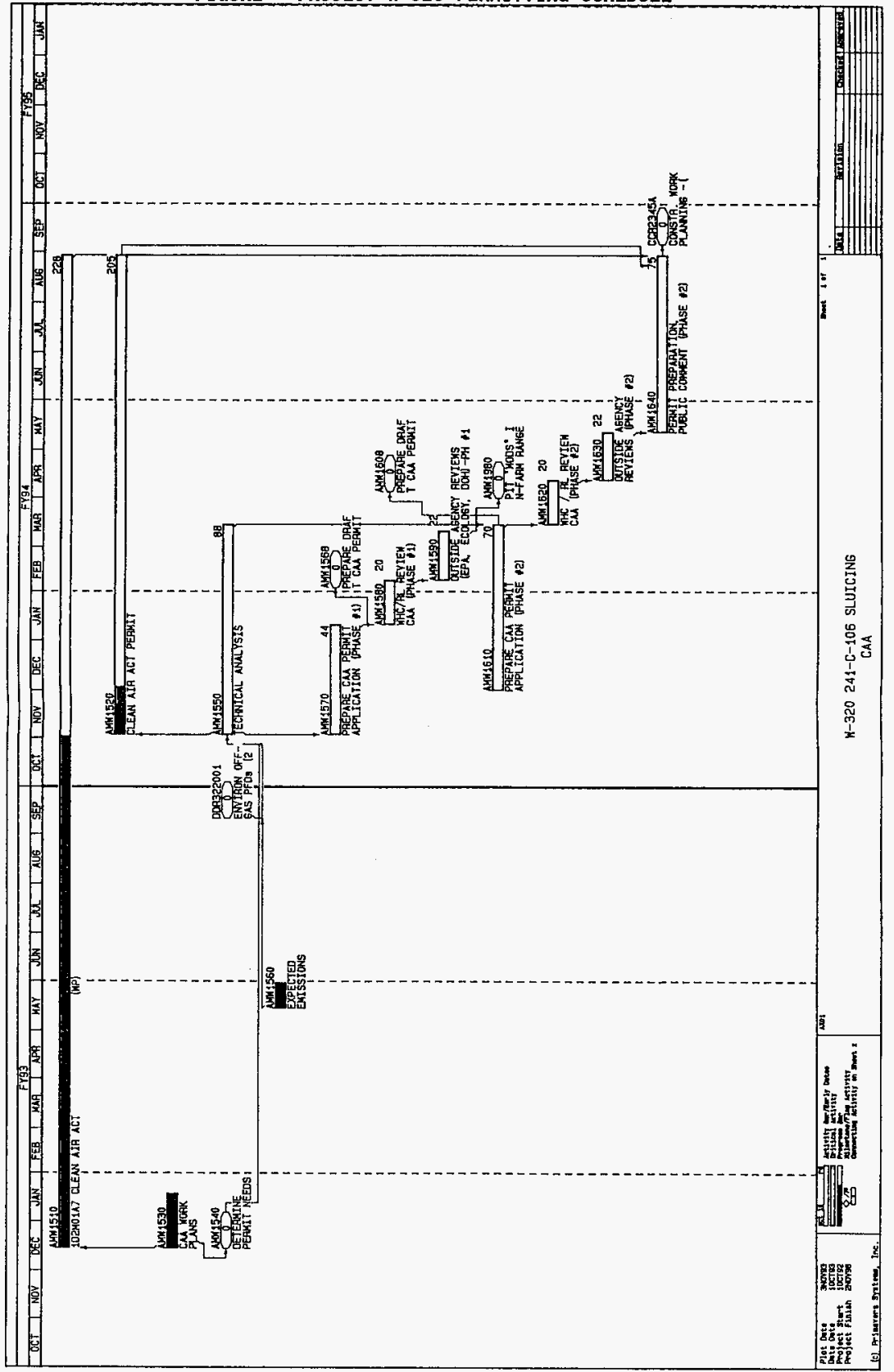

Figure - 25 


\section{HWF \\ WHC-SD-W320-EV-00I REV 0 \\ Gos}

(This page left intentionally blank.) 


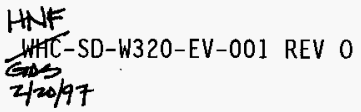

APPENDIX

SUMMARY OF DATA/INFORMATION REQUIREMENTS FOR THE TANK 241-C-106 WRSS 


\section{HNF \\ WHC-SD-W320-EV-001 REV 0 \\ ztapla7}

(This page left intentionally blank.) 


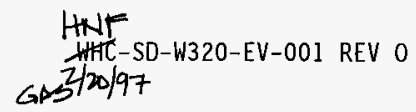

\section{Section 1.0 - National Environmental Policy Act}

The minimum data/information requirements for NEPA documentation preparation are:

1. Conceptual or equivalent design information.

2. Preliminary Safety Evaluation (PSE) including a "source term" to determine health effects and accident scenarios.

3. In addition, any other related engineering, safety, or waste evaluation documents would be helpful in NEPA preparation.

\section{Section 2.0 - State Environmental Policy Act}

The minimum data requirements for preparation of the SEPA environmental checkl ist include:

1. Conceptual or equivalent design information is needed in order to prepare the SEPA environmental checklist.

2. Any NEPA documentation that has been prepared or will be prepared for the Tank 241-C-106 WRSS.

3. Any other related engineering, safety, or waste evaluation documents would be helpful in SEPA environmental checklist preparation.

\section{Section 3.0 - Resource Conservation and Recovery Act}

The minimum data/information requirements for the N0I, Part A, Part B, and the RD\&D include:

\section{NOI and Part A Permit Application}

1. General nature of the process, capacities, justification of need, and volumes and flow rate is required for preparation of the NOI.

2. Preparation of the Part A requires CDR level of detail

\section{Part B Permit Application and RD\&D Permit Application}

1. Waste Minimization Plan

2. Building Emergency Plan

3. Tank Integrity Assessment (If Applicable)

4. Waste Analysis Plan

5. Process Plan

6. Contingency $\mathrm{Plan}$ 


\section{$H \mathrm{HF}$}

WHTC-SD-W320-EV-001 REV 0

7. Waste Characterization Plan

8. Training Requirements

9. Closure and Post Closure Plan

10. CDR (or equivalent information)

11. $80 \%$ Design for submittal to regulators

12. Final "Approved for Construction" Design (PE stamped) for public review.

13. Air Permits require approval prior to issuance of the permit.

Section 4.0 - Clean Air Act

Detailed information on the treatment process, the emissions abatement system, the gaseous effluent monitoring system, and the nature of all gaseous emissions to the atmosphere is required for submissions made pursuant to the Clean Air Act. The information listed below is an abridged summary of the data/information needs for the NESHAP and WAC 246-247 permit applications and Notice of Construction. The appropriate regulations and administrative guidance should be consulted for the detailed requirements.

\section{Radioactive Emissions}

\section{NESHAP Permit}

The 40 CFR 61.07 requires the application for approval to construct to include the following information:

1. Technical description of the facility and its operations

2. Size and location of the source

3. Design and operating capacity of the source

4. Method of operation (include process flow diagram)

5. Nature of all gaseous emissions to the atmosphere

- If a modification, the precise nature of the modification and estimates of emissions before and after completion

6. Technical description of emissions control system including release rates and off site doses 


\section{WAC 246-247 Permit}

The WAC 246-247 requires the application for approval to construct to include the following information:

1. Facility Information

- Description of facility operations

- Facility identification must be the same as that which appears on Source Registration Forms

2. Identification and 1 isting of all sources consistent with the Source Registration Identification

3. Description of the source(s)

- $\quad$ System function and area exhausted

- Effluent system layout

- Efficiency values of each control device for removal of radioactivity

- Means and frequency of testing and inspecting effluent treatment system

- Operating mode (continuous or batch)

- Chemical and physical nature of the emissions

- Stack or release point data

- Stack diameter and height

- Building height, width and length

- Annual ambient average stack and ambient air temperatures

- Annual wind rose

- Chi/Q data

- Annual average volumetric flow rate

- Annual average release rates

- Fraction of facility's inventory available for potential release to the air 
4. Description of the effluent sampling/monitoring systems

- $\quad$ Stack flow measuring system

- Sample probes (isokinetic)

- Number and location of sampling points

- Sample lines

- Diameters, lengths, materials, bends, entry points into the effluent line, angle of entry into the effluent

- Sample flow regulation

- Sampling media

- Frequency of sampling (continuous or batch)

- Frequency of sample collection

- Calibration and audit schedules

5. Environmental sampling monitoring system

- Sampling network (location, number, distance from release points)

- Media sampled/monitored for the air pathway

- Equipment used for sampling/monitoring, including sampler flow rate and collection media

- Frequency of sampling/monitoring

- Calibration and audit frequency

6. Hanford Site requirements for effluent sampling/monitoring system designs, procedures and quality assurance standards (appropriate standards and description of how they are used)

7. Effluent sample analyses including: methodology, procedure references, detection limits, quality assurance (including internal audit schedule and results)

8. Environmental sample analys is including methodology, procedure references, detection limits, quality assurance

9. Data from effluent and environmental monitoring programs, including background or local control data 
$H N F$

WHTC-SD-W320-EV-001 REV 0

a) 2097

10. Demonstration of comp 7 iance

- Methodology used to demonstrate compliance

- Input data used

- Source terms, release height, inhalation rate, maximally exposed individual, meteorology

- Results of method (effective dose equivalent for whole body and relevant organs)

- Description of internal standards used to ensure compliance with applicable state and federal laws and regulations

\section{Nonradioactive Air Emissions}

\section{PSD Permit}

The WAC 173-400 requires the application for approval to construct to include such information as:

1. Project location and emission source(s)

2. Design and operating parameters

- Hours of operation

- Normal and maximum production rates

- Fuel requirements

- Raw material requirements

- Emissions control system

3. Emissions - Type and Quantity

- Representative emissions from the existing source (for modification) over the most recent two year period of operation

- Projected actual controlled emissions at anticipated production rates and operating schedule for each pollutant at each emission point

- Projected potential controlled emissions; emission rate when equipment is operating at maximum capacity 24 hours per day, 365 days per year, taking air pollution control equipment into account 


\section{BACT/BARCT assessment}

- Literature search

- Control alternatives: comparison of efficiencies; energy, environmental, and economic impact analyses

- Summary

5. Analysis of current air quality at the proposed source location

- Presently existing ambient levels of the constituents being reviewed (from PNL data)

6. Analysis of the impact of the proposed source on ambient air quality

- Model description

- $\quad$ AIRDOS - EPA

- Meteorological data (windspeed, direction, temperature)

- Modeling results

- Offsite dose

7. Demonstration that the proposed emission will not cause a violation of state or national ambient air quality standards (NAAQS)

- Direct comparison of modeling results with NAAQS

8. Discussion of potential effects of the proposed project on factors influenced by air quality such as residential or commercial growth, vehicular traffic, vegetation, soils, acid deposition, visibility in sensitive areas, PSD increments, etc.

9. Construction schedute

\section{Notice of Construction}

The WAC 173-400 and 173-460 requires the application for approval to construct to include the following information:

1. SEPA checklist

2. Notice of construction form

3. Description of proposed source

- Bid specifications, rated capacity, inputs, outputs, and byproducts generated 


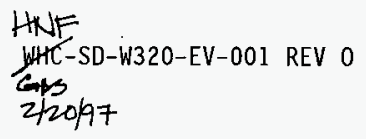

- Bid specifications, control efficiency, and operational requirements of the pollution control equipment

- Process flow diagram.

- Estimate of stack emissions, including criteria and toxic air pollutants

4. Estimate of fugitive (nonstack) emissions

5. BACT/T-BACT analys is

6. Modeling 